\title{
PENGARUH METODE PENEMUAN TERBIMBING (GUIDED DISCOVERY METHOD) DALAM PEMBELAJARAN MATEMATIKA TERHADAP KEMAMPUAN PENALARAN ADITIF SISWA KELAS XI MIPA 8 DI SMA NEGERI 2 BANGKALAN
}

\author{
SRI KUSNIAWATI \\ SMA Negeri 2 Bangkalan \\ e-mail: srikusniawati061@ gmail.com
}

\begin{abstract}
ABSTRAK
Tujuan penelitian ini adalah untuk menganalisis pengaruh metode penemuan terbimbing dalam pembelajaran matematika terhadap kemampuan penalaran adaptif siswa. Penelitian dilakukan di SMA Negeri 2 Bangkalan, Tahun Pelajaran 2019/2020. Metode penelitian yang digunakan adalah metode penemuan terbimbing(Guided Disovery Method). Subyek penelitian ini adalah 32 siswa yang terdiri dari 17 siswa putri dan 15 siswa putra pada siswa kelas XI MIPA8. Kemampuan penalaran adaptif siswa dikumpulkan dengan menggunakan tes. Hasil penelitian menunjukkan bahwa kemampuan penalaran adaptif siswa yang diajar dengan metode penemuan terbimbing lebih tinggi. Hal ini dapat dilihat dari nilai rata-rata hasil tes kemampuan penalaran adaptif siswa yang diajar dengan metode penemuan terbimbing siklus I adalah sebesar72,58 dan siklus II adalah 86,48.Dengan demikian, kesimpulan penelitian ini adalah pembelajaran matematika denganmenggunakan metode penemuan terbimbing mempunyai pengaruh yang signifikan terhadap kemampuan penalaran adaptif siswa.
\end{abstract}

Kata kunci: kemampuan penalaran adaptif, metode penemuan terbimbing

\section{PENDAHULUAN}

Tujuan pendidikan nasional adalah untuk mengembangkan kemampuan dan membentuk watak serta peradaban bangsa yang bermartabat dalam rangka mencerdaskan kehidupan bangsa, bertujuan untuk berkembangnya potensi peserta didik agar menjadi manusia yang beriman dan bertakwa pada Tuhan Yang Maha Esa, berakhlak mulia, sehat, berilmu, cakap, kreatif, mandiri, dan menjadi warga Negara yang demokratis serta bertanggung jawab. (Sopan Amri dan Iif Khoiru Ahmadi ,2010)

Pelaksanaan pembelajaran matematika di sekolah merupakan salah satu upaya yang dapat digunakan untuk mencapai tujuan pembelajaran dalam pendidikan. Pentingnya mempelajari matematika, tidak lain karena perannya dalam berbagai kehidupan, berbagai informasi dan gagasan yang banyak dikomunikasikan atau disampaikan dengan bahasa matematika. Pembelajaran matematika pada dasarnya bertujuan untuk melatih pola pikir dan pola sikap siswa.

Menurut Kilpatrick, dkk (2001) menyatakan bahwa tujuan pembelajaran matematika adalah membentuk pola pikir siswa yang dapat diukur dari kemampuan atau kecakapan yang dimilikinya, yang disebut dengan kecakapan matematika (mathematical proficiency) dimana terdapat lima jenis kompetensi matematika siswa yang perlu dikembangkan dalam pembelajaran matematika di sekolah, meliputi: pemahaman konsep (conceptual understanding), kelancaran berprosedural (procedural fluency), kompetensi strategis (strategic competency), penalaran adaptif (adaptif reasoning), dan berkarakter produktif(produktive disposition). Pendapat lain mengenai tujuan pembelajaran matematika diungkapkan oleh Widdiharto (2004), yang menyatakan bahwa :

Tujuan pembelajaran matematika adalah terbentuknya kemampuan bernalar pada diri siswa yang tercermin melalui kemampuan berfikir kritis, logis, sistematis, dan memiliki sifat objektif, jujur, disiplin dalam

Berdasarkan tujuan pembelajaran yang telah diungkapkan diatas, dapat dikatakan bahwa pengembangan dan pemanfaatan kemampuan penalaran siswa menjadi salah satu tujuan penting dalam pembelajaran matematika di sekolah. Kemampuan penalaran yang dimaksud 
adalah kemampuan penalaran adaptif dimana kemampuan ini sebagai bagian dari salah satu kompetensi matematika yang harus dikuasai siswa untuk dipakai dalam menyelesaikan suatu permasalahan.

Berdasarkan hasil observasi di SMA N 2 Bangkalan melalui wawancara dengan guru matematika kelas XI MIPA menunjukkan bahwa kemampuan penalaran adaptif siswa masih sangat rendah. Hal ini dapat terlihat dari siswa yang masih mengalami kesulitan ketika dihadapkan pada soal-soal matematika khususnya soal yang mengukur kemampuan penalaran adaptif dan guru kurang memperhatikan perkembangan kemampuan penalaran khususnya kemampuan penalaran adaptif siswa dalam kegiatan pembelajarannya.

Rendahnya kemampuan penalaran adaptif siswa tidak lain karena dipengaruhi oleh beberapa faktor, diantaranya adalah masih sedikit nya pembelajaran yang terjadi di sekolah dengan menerapkan kemampuan berpikir siswa untuk menyelesaikan masalah selama proses pembelajaran berlangsung.

Dari beberapa persoalan tersebut, maka dapat dikatakan bahwa kemampuan penalaran adaptif menjadi bagian penting yang masih harus dikembangkan dan dimiliki oleh siswa. Oleh karen itu, diperlukan suatu proses pembelajaran matematika yang dapat mengembangkan dan mengaplikasikan kemampuan tersebut dalam setiap tahapan proses pembelajarannya. Salah satu alternatif yang mungkin dapat dimanfaatkan untuk mencapai tujuan ini adalah dengan menerapkan metode penemuan terbimbing (guided discover method) dalam pembelajaran matematika.

Metode ini memberikan keleluasaan bagi siswa untuk melakukan penyelidikan dan menarik suatu kesimpulan dengan menggunakan terkaan, intuisi, dan mencoba - coba (trial and error) sesuai dengan pengalamannya (pengetahuan siapnya) sehingga siswa memiliki kesempatan untuk berperan aktif selama proses pembelajaran.

Tasker (1992) mengungkapkan bahwa terdapat tiga penekanan dalam teori belajar konstruktivisme meliputi : (1) peran aktif siswa dalam mengkonstruksi pengetahuan secara bermakna, (2) pentingnya membuat kaitan antara gagasan dalam pengkontruksian secara bermakna, dan (3) mengaitkan antara gagasan dengan informasi baru yang diterima. Teori belajar dari Bruner lebih dikenal dengan istilah pembelajaran penemuan (discovery learning). Teori belajar ini menindaklanjuti teori belajar konstruktivisme yang menyatakan bahwa siswa harus aktif di dalam kelas. Proses aktif tersebut dapat dilakukan dengan cara melalui suatu pembelajaran penemuan ((guided discovery method)) yaitu di mana siswa mengorganisasi bahan yang dipelajari dengan suatu bentuk akhir FRadjar Shadiq (2004) memberikan definisi tentang penalaran yaitu "suatu kegiatan, suatu proses atau suatu aktivitas berpikir untuk menarik kesimpulan atau membuat suatu pernyataan baru yang benar berdasarkan pada beberapa pernyataan yang kebenarannya telah dibuktikan atau diasumsikan sebelumnya. Metode penemuan (discovery learning) adalah "metode mengajar yang mengatur pengajaran sedemikian rupa sehingga anak memperoleh pengetahuan yang sebelumnya belum diketahuinya itu tidak melalui pemberitahuan, sebagian atau seluruhnya ditemukan sendiri"(.E.T.Ruseffendi-1979).Untuk itu guru matematika dituntut lebih aktif dalam memilih metode pembelajaran yang tepat bagi siswa.

\section{METODE PENELITIAN}

Peneltian ini merupakan penelitian tindakan kelas(action Research),karena penelitian ini untuk memecakan masalah pembelajaran dikelas . Metode penelitian ini menggunakan metode penemuan terbimbing (guided discovery method) Penelitian ini bertempat di Kelas XI MIPA SMA Negeri 2 Bangkalan Tahun Pelajaran 2018/2019. Waktu penelitian adalah waktu berlangsungnya penelitian atau saat penelitian ini dilangsungkan.Penelitian ini mengunakan dua siklus yang dilaksanakan pada bulan Februari semester genap tahun pelajaran 2018/2019. Subyek penelitian di sini adalah siswa kelas XI 8 MIPA SMA Negeri 2 Bangkalan Tahun Pelajaran 2018/2019 pada pokok bahasan Limit Fungsi. 


\section{HASIL DAN PEMBAHASAN}

Penelitian tindakan kelas ini terdiri dari 2 siklus. Setiap siklus terdiri dari 2 pertemuan dan satu pertemuan untuk post test, yang dilaksanakan sesuai dengan prosedur penelitian. Kuantitas pertemuan dalam setiap siklus didasarkan pada kepadatan materi yang dibahas.

Peneliti mengadakan pre tes sebelum pra tindakan hasil yang diperoleh hasil adalah rata-rata hasil belajar peserta didik yang diperoleh adalah 56,7 dengan ketuntasan klasikal $53,12 \%$.Untuk selanjutnya penelitian ini dilakukan sebanyak 5 kali pertemuan dengan rincian 4 kali pertemuan untuk memberikan perlakuan dan 1 kali pertemuan untuk posttest.

Tabel.1 Rekapitulasi Kemampuan Penalaran Aditif Siswa

\begin{tabular}{cccll}
\hline NO & Uraian & Pra & Siklus & Siklus \\
& siklus & I & II \\
\hline 1 & Nilai rata-rata & 56,7 & 72,58 & 86,48 \\
\hline 2 & Ketuntasan Klasikal & 53,12 & 62,5 & 85,67 \\
\hline
\end{tabular}

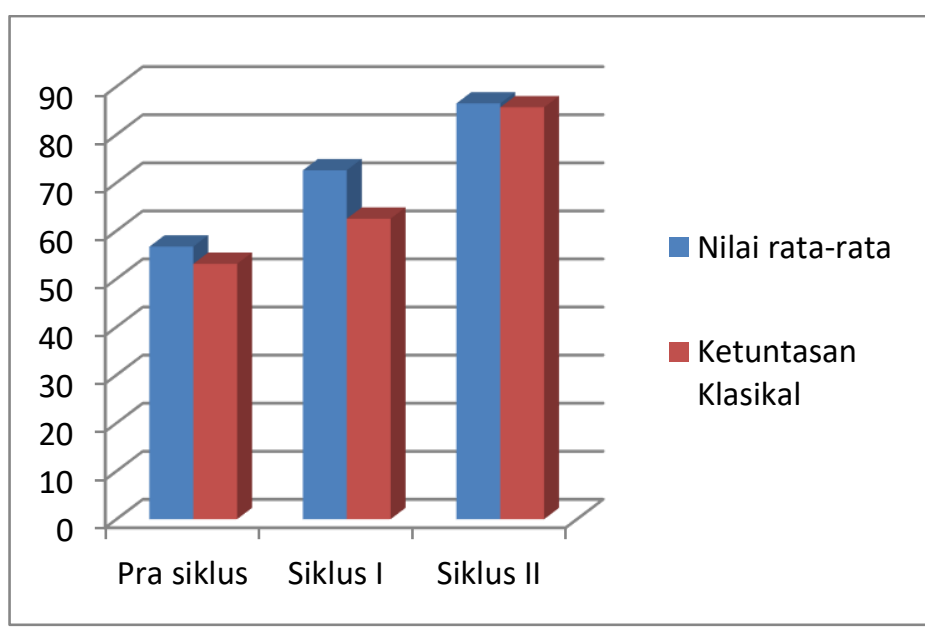

Gambar 1. Rekapitulasi Kemampuan Penalaran Aditif Siswa

\section{Pembahasan \\ Siklus I}

Peneliti menerapkan metode penemuan terbimbing (guided discovery method), pembelajaran memanfaatkan LKS yang terdiri atas : 1) guru membagi peserta didik dalam beberapa kelompok 2)guru memberikan rumusan masalah, 3) siswa melakukan kegiatan seperti menyusun, memproses, mengorganisir, dan menganalisis data, 3) siswa menyusun perkiraan jawaban, 4) guru memeriksa kebenaran dari hasil jawaban yang sudah dibuat, kemudian siswa menyusun sendiri kesimpulan dari kegiatan yang telah dilakukan, 5) guru memberikan soal latihan atau soal tambahan untuk memeriksa kebenaran penemuan itu serta tingkatpemahaman mereka. Rata-rata yang diperoleh peserta didik pada siklus 1 yaitu 72,58. Nilai ini telah mencapai KKM yang ditetapkan yaitu 70 Tetapi, ketuntasan klasikalnya belum terpenuhi yaitu $62,5 \%$, sedang indikator keberhasilan yang ditetapkan adalah $75 \%$. Pada pelaksanaan siklus I, pelaksanaan pembelajaran belum sesuai dengan yang diharapkan karena peserta didik belum memahami benar tentang prosedur pembelajaran dengan menggunakan model pembelajaran dengan metode penemuan terbimbing (guided discovery method). Hal ini dikarenakan dalam proses pembelajaran peserta didik belum terkondisi dengan baik. Sebagian peserta didik tidak tahu apa yang harus dikerjakan. Dikarenakan guru belum bisa menjelaskan jalannya pembelajaran dengan menggunakan metode penemuan terbimbing (guided discovery method). Serta Bimbingan yang diberikan oleh guru belum bisa menyeluruh. Selain itu waktu 
belum diatur dengan baik, sehingga ada tahap pembelajaran yang tidak dilakukan. Hal ini mengakibatkan rendahnya rendahnya pemahaman peserta didik terhadap materi yang dipelajari. Sehingga peserta didik kesulitan untuk menyelesaikan dalam pemecahan masalah yang ada.

\section{Siklus II}

Berdasarkan pengamatan, pada siklus 2 dimana guru memberikan tindakan pada siklus 2 berdasarkan refleksi pada siklus 1 dalam pelaksanaan siklus. Guru menggunakan metode penemuan terbimbing (guided discovery method) ini memfasilitasisiswa untuk menuangkan ide atau gagasannya pada LKS. Inilah yang menstimulus siswa untuk melakukan kegiatan berpikir. Pada tahap awal, guru memberikan rumusan masalah dalam bentuk pertanyaan untuk menstimulus siswa berpikir mencari solusi atau jawaban dari pertanyaan yang diberikan. Solusi tersebut berupa sebuah konsep yang nantinya ditemukan sendiri oleh siswa melalui kegiatan penemuan dalam LKS.

Tahapan berikutnya siswa melakukan kegiatan seperti : menyusun, memproses, mengorganisir, dan menganalisis masalah yang terdapat pada LKS. Tahapan ini merupakan kegiatan utama yang dilakukan oleh siswa dalam pembelajaran menggunakan metode penemuan terbimbing (guided discovery method). Siswa menggunakan kemampuan bernalarnya untuk menemukan konsepyang sedang dipelajari dengan mengerjakan beberapa langkah-langkah penemuan dalam LKS. Kemampuan yang digunakan oleh siswa pada tahapan ini meliputi kemampuan dalam menggunakan atau menghubungkan beberapa konsep yang sudah dipelajari dan melakukan kegiatan manipulasi terhadap beberapa langkah- langkah yang disediakan pada LKS. Untuk mengerjakan kegiatan dalam LKS, beberapa konsep prasyarat (pengetahuan yang sudah diperlajari) diingatkan kembali diawal sebelum melakukan kegiatan penemuan dan bimbingan diberikan seperlunya selama proses pembelajaran sehingga diharapkan siswa bisa mengerjakannya dengan baik dalam menemukan konsep yang ada pada LKS. Hasil penemuan yang diperoleh selanjutnya dituliskan oleh siswa sebagai jawaban sementara dan diperiksa secara bersama-sama dengan bimbingan guru.

Tahapan yang terakhir yaitu siswa mengerjakan soal latihan atau soal tambahan yang berkaitan dengan penguasaan konsep dan kemampuan penalaran adaptif sebagai kemampuan yang akan diukur dalam penelitian. Tahapan ini dilakukan untuk memeriksa kemampuan siswa dalam menggunakan hasil penemuan dan pemahaman siswa terhadap penguasaan materi yang sedang dipelajari serta kemampuan penalaran adaptifnya.

Tes akhir kemampuan penalaran adaptif siswa dilakukan pada akhir pembelajaran. Soal tes yang diberikan sebanyak 5 soal berupa essay. Dalampenelitian ini terdapat tiga indikator kemampuan penalaran adaptif yang diukur peneliti, yaitu :

a. Memberikan alasan atau bukti terhadap kebenaran suatu pernyataan

b. Memberikan Alasan atau bukti terhadap kebenaran suatu pernyataan

c. Memeriksa kesahihan dari suatu Argumen

Pada siklus II terbukti dengan pengaturan waktu yang baik, sehingga semua tahap pembelajaran bisa dilaksanakan dengan baik. Bimbingan yang diberikan oleh guru kepada peserta didik dalam kelompok dilakukan secara menyeluruh. Peserta didik sudah tidak bingung lagi dengan apa yang harus dikerjakan. Peserta didik berdiskusi dengan baik, sehingga peserta didik tidak kesulitan lagi untuk menyelesaikan pemecahan masalah yang ada.

Rata-rata hasil belajar peserta didik yang diperoleh dari siklus II adalah 86,48 dengan ketuntasan klasikal 85,67\%. Peserta didik yang telah mencapai kriteria tuntas sebanyak 26 anak sedangkan yang tidak tuntas sebanyak 6 anak. Hasil belajar peserta didik pada siklus 2 ini sudah memenuhi indikator yang ditetapkan, yaitu nilai rata-rata $\geq 60$ dan ketuntasan klasikal sudah mencapai $\geq 75 \%$ maka tidak perlu diadakan siklus berikutnya.

Pada penelitian ini diketahui bahwa terdapat peningkatan rata-rata kemampuan penalaran adaptif siswa dengan pembelajarannya menggunakan metode penemuan terbimbing (guided discovery method). Menurut Eggen dan Kauchak dalam Jacobsen, penemuan 
terbimbing adalah suatu metode pembelajaran yang disusun untuk menjelaskan konsep-konsep dan hubungan antar konsep. Konsep atau prinsip yang ditulis dengan jelas akan menciptakan pembelajaran yang terarah dan sistematis. Hal ini mempermudah guru dan siswa pada proses pembelajaran sehingga pembelajaran tersebut menjadi lebih bermakna. Berdasarkan hasil temuan penelitian terbukti bahwa kemampuan matematika siswa yang belajar menggunakan metode penemuan terbimbing lebih baik karena siswa diaktifkan dalam pembelajaran dengan langkah-langkah kegiatan yang menarik. Pembelajaran dengan penemuan terbimbing akan membangun konsep yang kuat karena ditemukan sendiri oleh siswa. Suasana pembelajaran pun lebih me-nyenangkan karena siswa berperan aktif dan guru hanya sebagai fasilitator.

Selanjutnya, Ruseffendi (2006) juga mengemukakan bahwa kemampuan pemecahan masalah amat penting dalam matematika, bukan saja bagi mereka yang di kemudian hari akan mendalami atau mempelajari matematika, melainkan juga bagi mereka yang akan menerapkannya dalam bidang studi lain dan dalam kehidupan sehari-hari.

Berdasarkan hasil temuan penelitian terbukti bahwa kemampuan matematika siswa yang belajar menggunakan metode penemuan terbimbing lebih tinggi karena siswa menemukan sendiri konsep yang dipelajari dengan adanya media belajar.

\section{KESIMPULAN}

Berdasarkan hasil penelitian seperti yang telah dikemukakan sebelumnya maka dapat disimpulkan bahwa:

Kemampuan matematika yang diajar menggunakan metode penemuan terbimbing lebih tinggi daripada kemampuan matematika yang diajar menggunakan metode ekspositori untuk siswa yang memiliki kemampuan berpikir kritis tinggi. Hal ini berarti penggunaan metode penemuan terbimbing memberikan pengaruh yang lebih efektif terhadap kemampuan matematika, dengan mempertimbangkan karakteristik kemampuan berpikir kritis siswa dalam pembelajaran akan lebih baik dan efektif.

\section{DAFTAR PUSTAKA}

Afgani,Jarnawi dan Eka Fitrajaa.(2006).Metode Pembelajaran Matematika Berbasis Keterampilan Berpikir dan Penalaran.Jurnal PeningkatanMutu Pembelajran Matematika dan Sains .Bandung:Mimbar Pendidikan.

Antik.(2006). Metode Penemuan Terbimbing.

(Online)https://antik2006.wordpress.com/metode-penemuan-terbimbing/. Diakses pada tanggal 16 maret 2015.

Asmawi Zainul dan Noehi. (1997). Penilaian Hasil Belajar. Jakarta: Dirjen Dikti UT.

Dani, Irfan. (2013). Metode Pembelajaran Penemuan Terbimbing. (Online) http://jalius12.ordpress.com/2009/10/06/model penemuan terbimbing diakses pada tanggal 9 Nopember 2011.

Kartawisatra, H., Una, Abimnyu., Soli dkk. (1999). Penemuan sebagai Metode Belajar Mengajar. Jakarta : Proyek Pengembangan Pendidikan Guru (P3G) Depdikbud.

Markaban. (2006). Model Pembelajaran Matematika dengan Pendekatan Penemuan Terbimbing. Yogyakarta : PPPG Matematika. 